\title{
PROPERTY-SYNDICATION INVESTMENT $V$ PROPERTY SCAM: WHO DECIDES? A CRITICAL EXAMINATION OF THE REGULATION OF PUBLIC-PROPERTY SYNDICATION SCHEMES IN SOUTH AFRICA
}

\author{
Tanya Woker \\ BA LLB LLM PhD \\ Professor, University of Kwazulu-Natal, Durban
}

\section{SUMMARY}

Building an investment portfolio is an important part of saving for retirement. This not only benefits the individual concerned but it also has benefits for the economy as a whole. Investment in property is regarded as an essential element of an investment portfolio and many investors have over the years invested in public-property syndications. Unfortunately such investments have proved to be very risky and there have been some spectacular failures with severe consequences especially for elderly, vulnerable consumers. There is a need to ensure that all investment opportunities are properly regulated and different aspects of property syndications are regulated by different regulators including the Reserve Bank, the Department of Trade and Industry, the newly established Consumer Commission and the Financial Services Board. There seems to be some confusion amongst regulators over which entity is ultimately responsible for ensuring that such investments are sound and reliable and that consumers can have faith that they are not investing in a scam. The fact that no one regulator is responsible for overseeing the full picture is problematic because it enables the unscrupulous to slip under the radar and avoid detection. This paper seeks to consider the question of which regulator is or should be responsible for regulating public-property syndications and to make some suggestions for reform going forward.

INTRODUCTION

Consumers are constantly being encouraged to save a portion of their income and to invest it in pension funds, unit trusts, insurance policies, shares and general savings accounts. ${ }^{1} \mathrm{~A}$ healthy investment portfolio will ensure that they

\footnotetext{
1 The Nel Commission Report The Final Report of the Commission of Enquiry into the Affairs of the Masterbond Group and Investor Protection in South Africa (April 2001) par 17 http://www.info.gov.za/view/DownloadFileAction?id=95667. In 2001 the South African Savings Institute (SASI) was launched. This is an independent non-profit organization dedicated to developing a robust savings culture in South Africa. Not only are there obvious benefits for 
are able to survive in times of economic hardship and can enjoy their retirement years when they are no longer earning a living. Property ownership is generally regarded as an essential element of any investment portfolio. ${ }^{2}$ However, consumers often have limited capital to invest in property and they do not have the expertise to manage such an investment. ${ }^{3}$ One way of doing this is to invest in a public-property syndication scheme. Through such schemes funds from numerous investors are pooled and then used to purchase or develop property. Most property syndications are structured as unlisted companies which purchase the properties and consumers then purchase shares in these companies. ${ }^{4}$

Property-syndication schemes as a form of investment became very popular in the 1990s. ${ }^{5}$ Interest rates were falling as were the returns on other forms of investments. There was a property boom and many, mainly elderly, investors were persuaded to invest their funds in these syndicates because of the promising returns which were being offered. For a period of time, interest in such schemes waned but they have again become a popular form of investment.

Unfortunately, over the years there have been a number of very large failed schemes with the result that many consumers have lost a great deal of money. History has demonstrated that investing in a public propertysyndication scheme is a very risky form of investment and such schemes may even be fraudulent. ${ }^{6}$ Recently, the Office of the Ombud for Financial Services

those individuals who save but there are also benefits for the economy as a whole. See www.savingsinstitute.co.za.

2 Consumer Affairs Committee Report in terms of $s$ 10(1) of the Consumer Affairs (Unfair Business Practices) Act, 1998 "An Investigation into Public Property Syndication Schemes" GG 2849610 February 2006 (Consumer Affairs Committee Report No 121) 5.

3 Ibid.

4 An unlisted company is a company which is not listed on a registered stock exchange such as the Johannesburg Stock Exchange (JSE). In order to trade on a licenced exchange, companies are required to meet certain requirements and such exchanges are regulated. In South Africa, the JSE is licenced to operate by the Financial Services Board (FSB). In some instances promoters have used other legal entities through which to promote their schemes such as close corporations or trusts. It is suggested that this is done in order to avoid the stringent requirements of the Companies Act 61 of 1973 now replaced by Act 71 of 2008. See Basson "Who Regulates Unlisted Public Offers" Summer 2006/2007 Auditing SA www.itnews. co.za/content/media/companydocs/ba60a357-50b3-4 (accessed 2013-02-20).

5 At that time property syndicates aimed at small investors grew from almost nothing into a R5 bn industry (Fife "They're so Smooth" 5 August 2005 Financial Mail http://secure .financialmail.co.za/05/0805/property/aprop.htm).

6 An example of a fraudulent scheme is Masterbond Property Holdings (Pty) Ltd (Masterbond). Consumers were encouraged to invest in the company for the purpose of financing major property developments such as the Fancourt golf course and hotel, Club Mykonos on the Cape West Coast and Marina Martinique in Jeffrey's Bay. The directors of Masterbond fraudulently claimed that the company was a registered bank whose deposits were protected by the South African Reserve Bank (see Kirk "Moneyweb Reported" http://www.money web.co.za/mw/content/en/moneyweb-special-Investigations?oid=329255\&sn=2009\%20Detail (accessed 2013-02-02); and The Nel Commission Report. Many investors were pensioners who lost their entire life savings in the scheme. Some recent examples include the scheme promoted by Deonette de Ridder, the chief executive of Realcor, who collected R650 million in investments from 3000 mainly elderly investors to build a hotel in Blaawberg. She was sequestrated in the Cape High Court on 18 March 2013 and has reportedly disappeared (19 March 2013 Die Burger). On 22 March 2013 the Supreme Court of Appeal handed down 
Providers (FAIS Ombud) ${ }^{7}$ declared the Sharemax public-property syndication to be no more than a ponzi scheme, in other words, an illegal pyramid scheme. ${ }^{8}$ Sharemax Investments (Pty) Ltd claims to be a real estate-property investment company which engages in renting, operating, and managing commercial properties for shops and offices. The company was incorporated in 1998 and is based in Pretoria, South Africa. ${ }^{9}$ However, the FAIS Ombud, after conducting a number of investigations following complaints from consumers found that investor's money was used to buy "empty firms with no value". ${ }^{10}$ It has been estimated that about 40000 investors invested R4.5 billion in the various schemes promoted and marketed by Sharemax, which, if it does turn out to be an illegal pyramid scheme will, according to Business Report make it the largest fraud in South African history. ${ }^{1}$

Consumers generally do not have the expertise to judge the validity and risk of many investment opportunities and therefore have to trust that there is a system in place which is designed to protect their interests. When investment opportunities fail investors, many of whom are pensioners, are often left destitute and without any means of recouping their losses. ${ }^{12}$ The question which this article seeks to answer is whether (and how) property syndication schemes are regulated and controlled. ${ }^{13}$ At present there seems

judgment in a matter involving a public property-syndication scheme promoted by Spitskop Village Properties Ltd (Spitskop) (Dulce Vita CC v Chris Van Coller (192/12 [2013] ZASCA 22 (22 March 2013)). The SCA found that although the scheme was not unlawful (despite the fact that the scheme contravened the Banks Act 94 of 1990 and the regulations issued in terms of Consumer Affairs (Unfair Business Practices) Act 71 of 1988) the promoters of the scheme used a "number of legal instruments to induce the gullible and the injudicious to invest large amounts of money in a scheme, which, when properly analysed, never had a reasonable prospect of succeeding" (par 37). Between July 2006 and May 2008 Spitskop received approximately R425 million from investors (par 11).

7 The role and functions of the FAIS Ombud are discussed below. The FAIS Ombud was established in terms of the Financial Advisory and Intermediary Services Act 37 of 2002 (FAIS Act).

8 Such schemes have been outlawed in many jurisdictions, including South Africa. Under the Harmful Business Practices Act, 71 of 1988 pyramid promotional schemes, money-revolving schemes and chain letters were declared to be harmful business practices and consequently unlawful by the Minister of Trade and Industry in 1999 (see GN 1135 GG 20169 1999-06-09). For a full discussion of such schemes see Woker "If It Sounds Too Good to be True it Probably Is: Pyramid Schemes and Other Related Frauds" 200315 SA Merc LJ 237. S 43 of the Consumer Protection Act, 2008 outlaws these schemes. The Consumer Protection Act repealed the Consumer Affairs (Unfair Business Practices Act) which was originally known as the Harmful Business Practices Act.

9 See Company Overview of Sharemax Investments (Pty) Ltd http://investing.businessweek. com/research/stocks/private/snapshot.asp?privcapld=116124337 (accessed 2013-02-12).

10 See Cokayne "Sharemax used Investors' Money to Buy 'Empty Companies with no Value'” 29 October 2012 Business Report http://www.iol.co.za/business/business-news/sharemax-usedinvestors-money-to-buy-empty-companies-with-no-value-1.1412596\#.URoMbB32-So (accessed 2013-02-12).

11 lbid.

12 Such failures can also have a "disastrous effect" on the economy. See Prakke Forensic Accountant Report prepared for Sharemax Investments (Pty) Ltd v Deon Basson Case No 3208/2006 (Prakke Report) https://docs.google.com/file/d/0BzvgHbVjpjvxVFMtMllfUmtCV FU/edit?pli=1 (accessed 2013-04-08)

13 The parliamentary finance committee raised this issue when it questioned the FSB in 2012. See Cameron "FSB Passes the Buck on Ponzi Scams" 25 November 2012 Personal Finance 
to be considerable uncertainty regarding this. ${ }^{14}$ There are a variety of different regulators who regulate different aspects of investment opportunities including the South African Reserve Bank (the Reserve Bank), the Department of Trade and Industry (DTI), the Registrar of Companies (now the Companies and Intellectual Property Commission (CIPC)), the Consumer Commissioner and the FSB together with the FAIS Ombud. ${ }^{15}$ In addition, these investment opportunities are often highly sophisticated and, when problems emerge, an extensive investigation is required, with investigating officials and regulatory authorities facing a barrage of legal challenges. ${ }^{16}$ The result is that matters drag on for years. This has the further result that repayment to consumers is often delayed (or may not happen at all) and that the funds available for repayment are depleted. In one particular matter involving Sharemax, the FAIS Ombud ordered a financial service provider (FSP) who promoted the scheme to repay a consumer R800 000. ${ }^{17}$ The FSP appealed to the High Court arguing that the FAIS Act ${ }^{18}$ gives FSPs the right to demand that the FAIS Ombud declines to deal with complaints lodged against them and refer

http://www.iol.co.za/business/personal-finance/financial-planning/financial/fsb-passes-the-buck -on-ponzi-scams-1.1429808 (accessed 2013-02-13).

14 Cameron "Call for New Measures to Stop Scams" 13 January 2013 http://www.vision brokers.co.za/blog/?p=3307 (accessed 2013-02-12).

15 See Swart and Lawack-Davids "Understanding the South African Financial Markets: An overview of the Regulators" 2010 31(3) Obiter 619.

${ }^{16}$ It took over 10 years to finalize the Masterbond matter and took a great deal of dedication, perseverance, and legal and business acumen on the part of the curators to recover some of the money invested in the scheme (see News24 "Masterbond Saga Almost Over" 2 September 2009 www.fin24.com/Companies/Masterbond-saga-almost-over-200209 (accessed 2013-04-09). Investigative journalists and auditors also report that they are threatened with legal action by lawyers representing such schemes when they raise red flags. Deon Basson, an investigative journalist who conducted an extensive investigation into Sharemax (which he compared to Masterbond) was sued by Sharemax for R20 million (North Gauteng High Court Case No 3208/2006). Basson died before the matter could be finalized, reportedly a broken man both financially and physically (see Heystek "Opinion: Deon Basson was Right About Sharemax" 1 February 2013 www.moneyweb.co/moneyweb-soapbox-tributeto-deon-basson (accessed 2013-02-09)). Basson was an independent researcher and consultant. He was an award-winning forensic financial journalist and honorary Professor of Auditing at Pretoria University. It is reported that he regularly tried to warn the Ministers of Finance and the DTI and their respective departments, the Registrar of Banks, and the FSB about Sharemax and personally commissioned the Prakke Report to assist him with his legal battle with Sharemax. The Pakke Report is "comprehensive and damning" and its author argues that the "investment structure through which Sharemax offered its attractive returns ... was both unsustainable and illegal" (see Cobbett "Trevor Manual Failed Sharemax Pensioners" 15 February 2013 www.moneyweb.co.za/moneyweb-special-investigations/didminister (accessed 2013-04-09). An email sent from Sharemax's legal representatives to the editor of ITI News, the internet site of the South African Insurance Times and Investment News, which published reports by Basson www.itinews.co.za/companyview.aspx?company= 106\&itemid=99 (accessed 2013-04-09).

17 The FAIS Ombud's jurisdiction is limited to R800 000. In fact the consumer had invested R1.8 million in the scheme but elected to abandon her full claim because she did not have the resources to take the matter to court (a common problem faced by many consumers) and had to rely on the FAIS Ombud for assistance. See Barnes and D Risk Insurance Consultants CC Case No FAIS 6793/10-11/GP1 (2 November 2011).

18 S 27(3)(c). 
those to court. ${ }^{19}$ The FSP also sought a declaration that the relevant section of the FAIS Act was unconstitutional on certain procedural grounds. The North Gauteng High Court rejected the application with costs and held inter alia that the FSP should have first exercised his right to lodge an appeal against the ombudsman's decision with the FSB's appeal board before approaching the court. The FSP is now pursuing that route. ${ }^{20}$ In the meantime, however, the pensioner is still without her funds whilst the FSP is supported by a legal team appointed and paid for by an insurance company, as he has professional liability insurance. $^{21}$

\section{BACKGROUND TO THE REGULATION OF PUBLIC- PROPERTY SYNDICATIONS ${ }^{22}$}

When property-syndication schemes first became popular in the 1990s concerns were expressed because they were not regulated. ${ }^{23}$ This led to the formation of the Public Property Syndication Association (PPSA), an autonomous body formed under the aegis of the South African Property Owners Association (SAPOA). Many syndication companies became members of the PPSA and their syndication prospectuses were submitted to the PPSA for information and comment. In addition a Consumer Code for Public Property Syndication Schemes was developed by the Business Practices Committee (the BPC), which was the predecessor to the Consumer Affairs Committee (the CAFCOM). ${ }^{24}$ The PPSA became dormant when public

19 Risk, Deeb Raymond And D Risk Insurance Consultants v The Ombud For Financial Services Case 38791/2011 North Gauteng High Court 4 September 2012 http://www. saflii.org/za/cases/ZAGPPHC/2012/199.pdf.

20 Cokayne 29 October 2012 Business Report in fn 10 above.

21 Van Zyl "Sharemax et al: Brokers to Pay Up" 10 September 2012 http://www.fin24.com/Com panies/Property/Brokers-to-pay-up-for-dodgy-schemes-20120910 (accessed 2013-02-20).

22 There are essentially two types of property-syndication schemes, namely private and public schemes. Private schemes occur when members of a family or a small group of friends get together to pool their funds in order to buy a property such as a holiday home or for investment purposes. Public property-syndication schemes relate to syndications where general members of the public are invited to participate in such schemes. It has never been the intention of regulators to influence private arrangements between family and friends. However, when members of the public who do not know the promoters and who may be influenced by advertising materials, are invited to participate in such schemes, it is important for there to be adequate safeguards in place to protect consumers. The focus of this article is on public property-syndications schemes.

23 CAFCOM Report No 121.

24 The CAFCOM was a committee established by the Minister of Trade and Industry under the Consumer Affairs (Unfair Business Practices) Act (hereinafter this Act will be referred to as the Unfair Business Practices Act for ease of reading and to avoid confusion with the Consumer Protection Act). The role of the committee was to investigate unfair business practices and to make recommendations to the Minister about how an unfair business practice should be dealt with. In some instance the Minister would issue regulations which effectively brought the business to an end, whereas in other instances the business practices would be regulated to ensure that consumers were not prejudiced. For further discussion of the CAFCOM see Woker "Business Practices and the Consumer Affairs (Unfair Business Practices) Act 71 of 1988" 2001 13(2) SA Merc LJ 315-323. The CAFCOM replaced the Business Practices Committee (BPC) when the Harmful Business Practices Act was amended by the Harmful Business Practices Amendment Act 23 of 1998. The name of the Act was changed to the Consumer 
interest in property syndications waned. However, in 2004 there was renewed interest in this form of investment and some negative reports appeared in the newspapers. The CAFCOM received a number of complaints concerning property syndications and in August 2004 the committee resolved to undertake an investigation in terms of the Unfair Business Practices Act into syndication schemes.

The CAFCOM investigation revealed a number of problems with property syndications. ${ }^{26}$ The primary problem related to the value which was placed on the property purchased or developed under the scheme. The property was often over-valued to attract investors. Investors were also given an unrealistic picture of promised returns. Elderly consumers were drawn to such investments because of the promises regarding income and they often did not understand or were not informed of the risks such as the costs related to the property. ${ }^{27}$ These included rates and taxes, commissions payable to leasing brokers, tenant-installation costs on re-letting, maintenance and the administration fee for managing the property. All such costs were deducted before any income was payable to investors. Finally investors faced substantial difficulties if they wanted to liquidate their investments because they could only sell their shares in the entity if another buyer could be found. It was usually only at the time that the investors were no longer receiving their promised returns that they wanted to sell and, because this generally meant that the scheme was failing, no new buyers could be found. ${ }^{28}$

Following its investigation the committee concluded that consumers have the right to choose their form of investment but that they had to be made aware of the facts so that they could make informed decisions. The committee therefore decided not to advise the Minister of Trade and Industry (the Minister) to prohibit property syndications from operating altogether but rather to regulate the sector. The intention was to ensure that consumers were given sufficient information in order to make informed decisions before investing in such syndications. The committee recommended that certain prescribed minimum information be made available to consumers in a disclosure document. ${ }^{29}$ The Minister accepted the CAFCOM's recommendations which subsequently became regulations. ${ }^{30} \mathrm{~A}$ promoter of a public propertysyndication scheme who did not comply with these disclosure requirements

Affairs (Unfair Business Practices) Act 71 of 1988 and the name of the Committee was changed to the CAFCOM. The Unfair Business Practices Act was repealed when the Consumer Protection Act, 2008 became fully operative in 2011. The committee was replaced by the Consumer Commission.

25 Notice of the investigation was published under Notice 2137 in GG 26833 of 2004-09-23.

26 See the CAFCOM Report No 121.

27 This was a constant complaint raised during the FAIS Ombud's investigations. See for example Barnes and D Risk Insurance Consultants CC supra par 13.1; and Salmond and D Risk Insurance Consultants CC Case No 6520/10-11/GP 1 par 7 (29 November 2011).

28 In 2007 a reporter with ITI News, the internet site of South African Insurance Times and Investment News, reported that barely a month went by without an intermediary contacting him regarding the difficulty of realizing their client's money in one or other property-syndication scheme (Wilson "How to Get your Money from Sharemax" 15 November 2007 www.itinews.co.za/news. aspx?categoryid=8\&subcategoryid=1222 (accessed 2013-09-09).

29 See Annexure A of the Report.

30 GG 28960 2006-03-30. 
was committing a criminal offence and was liable on conviction, to a fine not exceeding R200 000 or to imprisonment for a period not exceeding five years or to both. ${ }^{31}$

Whether or not these regulations had any impact on the promotion of public-property syndications is difficult to evaluate. There are no reported cases where promoters were prosecuted for contravening the regulations and yet a number of significant property syndications failed after they were promulgated. ${ }^{32}$ Those investigating the industry, such as financial journalists were, however, aware of the regulations and would refer to them in their research. ${ }^{33}$ Given the fact that there seems to have been a rise in the number of consumers losing their money in such schemes it must be questioned whether these disclosure requirements have had the desired effect. ${ }^{34}$ In a recent investigation by the FAIS Ombud into the Sharemax scheme, the Ombud pointed out that Sharemax has a 99-page disclosure document which is full of legal terminology. It seems safe to assume that many vulnerable and elderly consumers who were lured by the promise of high returns would not have understood the high-risk nature of the investments they were entering into. The investigations conducted by the FAIS Ombud also reveal that investors entered into such investments on the advice of their investment advisors. This then leads to the next question, which is: what is the role of the FSB? This is discussed further below.

In addition to any regulatory role which the FSB or DTI may have, the Reserve Bank also has a role to play in the control of such schemes. The Reserve Bank is responsible for bank regulation and supervision in South Africa and it monitors activities governed by the Banks $\mathrm{Act}^{35}$ and the Mutual Banks Act. ${ }^{36}$ In 2010 the Registrar of Banks concluded that Sharemax was

${ }^{31} \mathrm{~S} 12$ of the Unfair Business Practices Act.

32 In Dulce Vita CC v Chris van Coller supra the SCA pointed out that the evidence suggested that some if not all the promoters carried on the business of Spitskop recklessly or with intention to defraud the investors and so could have committed a criminal offence under the Unfair Business Act (as well as other Acts) and so could be liable to a fine or a term of imprisonment. It must be noted that, when a person or entity contravened regulations promulgated under the Unfair Business Practices Act, the matter had to be referred to the South African Police Services for investigation. The CAFCOM dealt with unfair business practices, not criminal activity. During Basson's investigation into Sharemax, Moneyweb sent a letter to the DTI asking whether any action had been taken against Sharemax. The response was that complainants had been referred to the FSB and it was pointed out that the CAFCOM had no jurisdiction over a business which engaged in conduct which had already been prohibited by the Minister. The matter had to be referred to the SAPS and the NPA. Corbett's article "Trevor Manual Failed Sharemax Pensioners" has reprinted this letter.

33 See, eg, Basson 2006/2007 SA Summer, where Basson raised the question whether these new disclosure requirements were even necessary given the fact that the Registrar of Companies already had certain powers conferred on him by the Companies Act, and if one section of the DTI was unable to solve the problem it was unlikely that another division within the DTI would be able to do so. This is discussed further below. See also note 16 above.

34 In presenting her Annual Report in 2012 the FAIS Ombud raised concerns about the "rise in the number of consumers who put their hard-earned savings into black holes on the basis of lamentably bad advice wrapped in fancy presentations and accompanied by marketing material devoid of any fact, which could enable consumers to make informed decisions". Cokayne 29 October 2012 Business Report in fn 10 above.

35 Act 94 of 1990.

36 Act 124 of 1993. 
obtaining funds illegally from the public and that this contravened the Banks Act. $^{37}$

When the syndication is operated through a public company the scheme must comply with the Companies Act. ${ }^{38}$ The Companies Act of 1973 has now been replaced by the Companies Act of 2008 which creates a totally new structure for the regulation of companies in South Africa. However, the Companies Act still requires that an offer of shares (referred to as securities under the new Companies Act) may not be made to the public unless it is accompanied by a prospectus. This is the principal document that provides potential investors with information on which to base their investment decisions. The Companies Act provides that every prospectus must contain sufficient information regarding the state of affairs of the company to enable consumers to make an informed decision before they purchase shares. ${ }^{39}$ Under the old Companies Act the comment was made that these requirements create the impression that that an external auditor will verify the projections made by promoters and that the Registrar of Companies was regulating all such schemes. This was also used as a marketing tool by promoters to give syndication schemes an air of legitimacy. ${ }^{40}$ In practice, however, the Registrar of Companies was "little more than a filing office" and it did not have the "staff with the necessary expertise to establish whether or not a prospectus contained a fair presentation of the state of affairs of the company concerned". ${ }^{41}$

As stated above, the new Companies Act has overhauled the legal framework for the regulation of companies. The requirements for incorporating a company have been relaxed as incorporation is seen as a right rather than a privilege imposed by the state, ${ }^{42}$ but the Act imposes stringent financial reporting requirements. This is to balance accountability and transparency against the less stringent registration burden. So, whilst it may be easier to register a company, once registered the company and its directors are obliged to comply with stringent requirements. Those who fail to comply with their duties under the Act will be committing a criminal offence. ${ }^{43}$ All companies must prepare annual financial statements (AFSs) and public companies must undergo an annual audit. All companies must file an annual return with the Commission and public companies are required to file their annual audits with their returns. Public companies must appoint a company secretary, auditors and an audit committee. The financial statements must satisfy prescribed reporting standards. Companies must rotate the auditor on a regular basis as no auditor may act for more than five consecutive financial years. The

37 Cokayne 29 October 2012 Business Report in fn 10 above.

38 Act 71 of 2008 replaced Act 61 of 1973.

39 S 148 (Act 61 of 1973 and s100 Act 71 of 2008).

40 Willie Botha, a director of Sharemax made such claims in a letter written to Moneyweb at a time when another property syndication scheme, regarded as one of Sharemax's main rivals, had gone into liquidation (see Investment Insights "Sharemax Fires Another Salvo" 24 October $2007 \mathrm{http} / / / \mathrm{www}$.moneyweb.co.za/moneyweb-property/sharemax-fires-another-salvo2 (accessed 2013-02-20).

41 The Nel Commission Report 40.

42 See www.cipc.co.za/publications_files/Companies-Act_guidepdf 19 (accessed 2013-04-10).

43 S 214 of the Companies Act, 2008. 
functions of the CIPC include registration of companies and ensuring the efficient and effective enforcement of relevant legislation. The CIPC must also monitor compliance with and contraventions of the new financial reporting standard introduced by the Act. The Act also provides for the establishment of the Companies Tribunal which will act as a forum for voluntary alternative dispute resolution in any matter arising out of the Act and to carry out reviews of administrative decisions made by the Commission. ${ }^{44}$

It is hoped that these new developments will lead to a much closer monitoring of public companies but the CIPC must be resourced adequately with sufficiently trained staff to enable it to understand the documents which public companies are required to submit, including the prospectus and to ensure that the previous position of simply acting as a filing system does not continue. There needs to be active and efficient monitoring by the Commission of all offerings through public companies and, if this does occur, this may go some way to alleviating the problem. ${ }^{45}$

\section{THE FINANCIAL SERVICES BOARD (FSB)}

The FSB is a unique, independent institution established in 1990 by the Financial Services Board Act, ${ }^{46}$ to regulate the South African non-banking financial services industry. ${ }^{47}$ The aim of the FSB is to promote and maintain a sound financial investment environment in South Africa to ensure that investors are protected. Financial service providers (FSPs) must register with the FSB and must have an FSP licence to provide advice and sell particular products. Financial representatives/advisors employed by a particular FSB are then entitled to provide advice under that FSP's licence. A major function of the FSB is to to ensure that regulated entities comply with the relevant legislation as well as capital-adequacy requirements. The FSB also advises the Minister of Finance on matters concerning financial institutions and financial services and it educates consumers regarding financial products and services. ${ }^{48}$ The FSB regulates financial institutions and services in terms of 12 statutes, the most important being for the purposes of this article the Financial

44 However, the High Court remains the primary forum for the resolution of disputes and the interpretation and enforcement of the Act.

45 In the past questions have been raised about the role of auditors with regard to the promotion of some fraudulent schemes, so by requiring that auditors be rotated there may be more chance of identifying problems (see Cobbett "Property Syndicators Auditor Clobbered" 10 December 2009 http://www.moneyweb.co.za/moneyweb-special-investigations/property-syndi cators-auditor-clobbered (accessed 2013-04-18). But still compliance needs to be efficiently monitored.

46 Act 97 of 1990 (the FSB Act).

47 FSB "Strategic Plan 2010/2011-2012/2013" ftp://ftp.fsb.co.za/publicdocuments/strategic plan2010 (accessed 2013-04-03). The FSB was established after recommendations made by the Van der Horst Committee established to examine the deficiencies of South African law with regard to the protection of investors in the non-banking financial sector.

48 See Manual On Access To Information Held By The Financial Services Board Compiled In Terms Of Section 14 Of The Promotion Of Access To Information Act, 2 Of $2000 \mathrm{ftp}: / / \mathrm{ftp}$. fsb.co.za/public/documents/PAIAManua04042011.pdf and the FSB Strategic Plan 2010. 
Advisory and Intermediary $\mathrm{Act}^{49}$ (FAIS) and the Collective Investment Schemes Act ${ }^{50}$ (CISCA).

\section{The FAIS Act $^{51}$}

The introduction of this Act in 2004 together with the creation of the FAIS Ombud, substantially expanded the mandate of the FSB to regulate the conduct of intermediaries/advisors who provide financial advice to consumers. The FAIS Act regulates the activities of all FSPs and their representatives in terms of a code of conduct that sets guidelines for business practices within the financial services industry, among other fundamental rules. ${ }^{52}$ The code requires that financial services must at all times be provided honestly, fairly, and with due skill, care and diligence. FSPs and their representatives are obliged to provide advice that is suitable and in the best interests of the client, based on his/her financial situation, experience of financial products and objectives; and to identify the client's risk profile and financial needs. They are obliged to keep a record of advice that contains a summary of the information and material on which their advice was based, the products that were considered and an explanation of why the products would satisfy their client's needs. FSPs must provide consumers with full details of all amounts, charges, fees, remuneration and monetary obligation and they must also disclose to consumers any interest they may have in a product or service provider. ${ }^{53}$

It is important to note is that it is only the FSP which is required to be registered with the FSB, not each and every financial representative/advisor employed by the FSP. Financial advisors employed by FSPs are entitled to provide advice under the registered FSP's licence. It is the responsibility of the FSP to ensure that its financial advisors are competent and comply with their obligations under the code. Unfortunately in recent times it seems that this process has been abused. In her determinations relating to property syndications, the FAIS Ombud found that property-syndication companies rented out their licences, either directly, or indirectly through associated companies. Sharemax actually set up a company, FSP Network Limited, a

49 Act 37 of 2002.

50 Act 45 of 2002 .

51 The FAIS Act was introduced after the Nel Commission of Inquiry (which investigated the Masterbond collapse) found serious shortcomings in the existing state of the law governing the conduct of agents, representatives, advisors and intermediaries who promote investments to consumers.

52 See General Code of Conduct for Authorised Financial Services Providers and their Representatives promulgated under section 15 of the FAIS Act 37 of 2002.

53 A key issue which consumers could consider is the amount of commission which advisors are being paid to sell investments. When consumers are able to compare different products they may be able to establish whether such commission is reasonable. See Downey "Is your Financial Adviser Giving you Fair Advice?" http://www.glassock.co.za/news/entry/is your financial_adviser_giving_you_fair_advice/ (accessed 2013-02-20). This issue was discussed in the Prakke Report (par 16). For every R100 invested in Sharemax at least R10 and sometimes as much as R20 went towards broker's commission, syndication costs and marketing costs. By way of comparison property unit trusts have much lower costs, more in the region of $1 \%$ which includes stockbroker commission (South African Commercial Property "Should Brokers be Selling Sharemax" 27 November 2007 www.commercialproperty.co.za/1600_news_Should-brokers-be-selling-Sharemax (accessed 2013-04-09). 
licenced FSP, which traded as Unlisted Securities of South Africa (USSA), to enable independent representatives in the financial services industry to market and sell unlisted shares in a property syndication to members of the public. ${ }^{54}$ Most of the representatives listed under USSA did not have a licence to render advice or intermediary services in their own capacity but USSA facilitated that for them under its licence in return for a monthly contribution. ${ }^{55}$

\section{Collective investment Schemes Act (CISCA)}

CISCA regulates collective investments. The legislation was initially aimed at regulating unit-trust funds only, but it has been expanded to include mortgageparticipation bond (part bond) schemes, where investors' money is pooled to finance large property developments. Similar to property syndications such schemes involve the pooling of funds from a group of investors to form collective investments-schemes portfolios. These portfolios are managed by collective investment-scheme managers who use these pooled funds to invest in a wide range of top-class securities including shares listed on an exchange such as the JSE, industrial and commercial property, and interest-earning investments. Collective investment schemes must be registered with the FSB and in terms of CISCA, whether they invest in property, shares or bonds, they must meet certain requirements and are limited as to how much of an underlying investment they may own in order to ensure that the risk is spread. By the end of December 2012 there were 967 registered collective investment funds in South Africa. The total assets under management were R1.3 trillion. ${ }^{56}$ CISCA provides protection for investors' money because in terms of the Act, funds from investors must be held by an independent custodian (usually a bank) which must be approved by the FSB and which acts on the instructions of an asset manager. This means an asset manager does not have direct access to the funds as has happened in so many unregulated investment schemes such as property syndications. ${ }^{57}$ These are also fairly versatile investments because investors can have access to their money fairly quickly, usually within 48 hours.

Although property syndications are in effect collective investment-type schemes, CISCA does not govern these schemes because of the definition of

${ }^{54}$ See Siegrist $v$ Botha Case No FAIS 00039/11-12GP1 par 17 determination handed down 24 January 2013.

55 lbid.

56 See Barry "Collective Investment Scheme Figures Show Investors Favour Intermediaries" 30 January 2013 http://www.risksa.com/life/collective-investment-scheme-figures-show-investorsfavour-intermediaries (accessed 2013-03-05); and Cairns "The State of SA's Unit Trust Industry" 11 March 2013 http://www.moneyweb.co.za/moneyweb-south-africa/the-state-of-sasunit-trust-industry (accessed 2013-03-11).

57 In many instances the funds from investors are used to fund the luxurious lifestyles of the promoters. City Press managed to trace about 250 million of assets owned by trusts and companies of Sharemax's former director and his marketing manager. These assets included a luxury yacht which was kept in an Egyptian port, two game farms, one valued at R79 million and an exclusive villa in Pretoria Prakke stated that $80 \%$ of the money invested in Sharemax is reported to have disappeared. (Pauw "The Luxurious Lives of Sharemax Bosses" 13 November 2011 www.fin24.com/companies/property/The-luxurious-lives-of-sharemax-bosses (accessed 2011-04-09). 
a collective investment contained in the Act. A collective investment scheme is defined as

"a scheme in whatever form, including an open-ended investment company, in pursuance of which members of the public are invited or permitted to invest money or other assets in a portfolio, and in terms of which -

(a) two or more investors contribute money or other assets to and hold a participatory interest in a portfolio of the scheme through shares, units or any other form of participatory interest; and

(b) the investors share the risk and the benefit of investment in proportion to their participatory interest in a portfolio of a scheme or any other basis determined in the deed,

but not a collective investment scheme authorised by any other Act."

Property-syndication scheme investors usually acquire shares in a company and then, as shareholders, they pool their funds in order to acquire property. This means that the investor's interest in the property is indirect. This does not qualify as a collective investment scheme as defined in CISCA as the investors do not own the underlying assets of the company, but rather they own a share in the company itself. In order for a scheme to qualify as a collective investment scheme, there must be a pooling of funds of investors (two or more members of the public), which funds are used to acquire assets to which each investor is entitled through a participatory interest.

In short, therefore, this means that public-property syndications do not qualify as collective investments as they are presently defined and consumers are not protected by the requirements set out in the legislation.

\section{RECENT DEVELOPMENTS}

\section{The Consumer Protection Act $^{58}$ (CPA)}

In April 2011, the CPA became fully operative and the Unfair Business Practices Act was repealed. This meant that all the regulations promulgated by the Minister under the previous Act, including the regulations dealing with property syndications were also repealed. In order to deal with this situation and to ensure that property syndications continued to be regulated, the regulations to the CPA contained regulations governing property syndications. ${ }^{59}$ These regulations are simply a reproduction of the regulations which were promulgated by the Minister of Trade and Industry under the now repealed Unfair Business Practices Act. Promoters of public-property syndication schemes are obliged to provide the same information as before in a disclosure document or prospectus and failure to do so will amount to prohibited conduct. ${ }^{60}$ Persons or entities that are engaged in prohibited conduct can be referred to the Consumer Commission for investigation ${ }^{61}$ and if the Commission is of the view that there is prohibited conduct it can refer

58 Act of 2008.

59 Regulation 15.

60 Prohibited conduct is widely defined in the CPA as an "act or omission in contravention of this Act"s 1).

$61 \mathrm{~S} 72$ of the CPA. 
the matter to the Consumer Tribunal for a hearing. ${ }^{62}$ If the Tribunal finds that there has been prohibited conduct it can impose a number of penalties, including an administrative penalty of $10 \%$ of the entity's annual turnover or R1 million, whichever is the greatest. ${ }^{63}$ An affected consumer will then be able to obtain a certificate from the chairperson of the Tribunal stating that the person or entity has been found by the Tribunal to have engaged in prohibited conduct and the affected consumer may proceed to the High court in order to claim damages. ${ }^{64}$ The certificate from the chairperson will constitute proof of the prohibited conduct, and so the consumer will not have to prove this again in court, he or she will simply have to prove his/her damages. ${ }^{5}$ The CPA also makes provision for a class action; therefore a number of affected consumers will be able to work together to bring an action against those engaged in prohibited conduct, thereby alleviating the problem of substantial legal costs. ${ }^{66}$

There are a number of problems with these regulations. Firstly, they are simply a reproduction of the previous regulations, which as discussed above, seem to have been relatively ineffective when it comes to solving the problem. According to the FAIS Ombud the number of consumers who have invested in failed property-syndication schemes appears to be increasing and not decreasing, despite the fact that such schemes provide very extensive and impressive disclosure documents. The second and probably a more serious problem is that these regulations could well be invalid. This is argued because these regulations were promulgated in terms of section 42 of the CPA which deals with fraudulent schemes and offers. Section 42 is designed to deal with so-called "419 scams" which are also known as "Advanced Fee Frauds". 419 scams began in West Africa but criminals who perpetuate these frauds are found the world over. ${ }^{68}$ Generally victims receive unsolicited communications such as letters, faxes, emails or sms's which purport to promote services or products such as oil products, real estate, the distribution of an inheritance, over-budgeted money or lotteries. The communications often purport to come from a government agency, ${ }^{69}$ a recognized bank or a

62 S 73 of the CPA.

$63 \mathrm{~S} 112$ of the CPA.

$64 \mathrm{~S} 115$ of the CPA.

$65 \mathrm{~S} 115(3)$ of the CPA

$66 \mathrm{~S} 4(1)(\mathrm{c})$ of the CPA.

67 The fact that this section is intended to govern 419 scams in confirmed in the "Memorandum on the Objects of the Consumer Protection Act, 2008" which was published when the final version of the Act was published. In this memorandum the following comment is made: "The Bill retains the existing prohibitions against fraudulent schemes and offers, pyramid and related schemes" (85). Such scams were originally prohibited by the Minister in terms of regulations published under the Unfair Business Practices Act (see GN 1643 of 2001 GG 22459 2001-07-13 and GN 2005 GG 27414 2005-03-24). Information about these scams can be found on the internet. See, eg, http://www.crimes of persuasion.org and http://www. fraudwatchers.org and www.fbi.gov/scams-safety/fraud/fraud\#419. They are named after the relevant section in the Nigerian Criminal Code which outlaws this practice.

68 In 2004 it was reported South Africans had lost in the region of R100 million to 419 fraudsters and that a British citizen had lost R32 million, an American R6 million and a Canadian R5 million. See Naidu "419 Fraud Schemes net R100 Million in SA" http://www.iol.co.za/ general/news/newprint.php?art id=ct2004030710560989S52026\&sf= (accessed 2012-09-20).

69 In 2004 it was established that the names of South African government officials were being used in fraudulent letters (Naidu "419 Fraud Schemes"). 
major legitimate corporation. ${ }^{70}$ The CPA specifically identifies three different kinds of fraudulent schemes which no person may promote or knowingly join, enter into or participate in. These are a fraudulent currency scheme ${ }^{71}$ a fraudulent financial transaction ${ }^{72}$ and a fraudulent transfer of property or rights. ${ }^{73}$ The Minister may also, by regulation, prohibit any other arrangement, agreement, practice or scheme if it is similar in purpose or effect to one of the specifically defined schemes. ${ }^{74}$ This subsection will allow the Minister to prohibit any scheme which has been devised by an ingenious entrepreneur who is attempting to avoid the definitions contained in section 42 . Under the Unfair Business Practices Act, the Minister of Trade and Industry could prohibit any business transaction, if such business transaction was regarded as unfair to consumers or had the potential to prejudice consumers. The Unfair Business Practices Act itself did not prohibit anything and was an enabling Act rather than a prescriptive one. The CPA, on the other hand, defines prohibited conduct in definite terms. The result is that the flexibility of the Unfair Business Practices Act has been lost and unscrupulous entrepreneurs may attempt to avoid definitions with ingenious schemes. ${ }^{75}$ This provision as well as the one in section 43(2)(b) (which deals with pyramid and related schemes) will enable the Minister to keep up with these developments by making regulations, provided the scheme has the same purpose or effect as the ones which have been prohibited.

The Minister has relied on section 42(8) to prohibit certain schemes which were regulated previously under Unfair Business Practices Act. These are transport contracts, ${ }^{76}$ property-syndication schemes and feasibility studies which promise funding. Bringing transport contracts and property-syndication schemes under the section, which regulates fraudulent schemes and offers, is problematic because the section was designed specifically to deal with 419 scams. These fraudulent schemes are very different to transport contracts and property-syndication schemes. Certain aspects of transport contracts and property-syndication schemes were regulated under the Unfair Business Practices Act because those aspects had the potential to be prejudicial to

70 Old Mutual, eg, has published a fraud alert in this regard http//:www.oldmutual.co.za/aboutus/governance/compliance/fraud-alert.aspx (accessed 2012-09-20).

$71 \mathrm{~S} 42(2)(\mathrm{a})$ of the CPA.

$72 \mathrm{~S} 42(2)(\mathrm{b})$ of the CPA.

${ }^{73}$ Section $42(2)(c)$ of the CPA.

74 Section 42(2)(d) of the CPA read with s 42(8).

75 One of the criticisms leveled against the previous legislation was that the legislature did not define unfair business practices, but rather left it to the Minister (and the CAFCOM) to investigate and then pronounce on the conduct adverse to consumers. It was felt that this often left business in the precarious position of not knowing whether or not it might find itself on the wrong side of the law at a later stage when it had invested considerable time and money in its businesses. In adopting the more rigid definitions of prohibited conduct in the CPA the legislature has heeded this criticism but the down side is that the flexibility of the previous legislation has been lost. See generally Woker "Why the Need for Consumer Protection Legislation? A Look at Some of the Reasons Behind the Promulgation of the National Credit Act and the Consumer Protection Act" 2010 31(2) Obiter 218; and Janse Van Rensburg NO v Minister of Trade and Industry 2001 (1) SA 29 CC, where it was argued that the extremely wide definition of an "unfair business practice" contained in the repealed legislation was unconstitutional because it created uncertainty.

76 The previous regulations were set out in GN 480 GG 15744 1994-05-20. 
consumers. However, the schemes themselves could be promoted quite legitimately. Section 42 is intended to regulate fraudulent schemes but it is clear that these regulations apply to all promoters of property-syndication schemes. Sub-regulation 15(4) which requires a promoter to make available the prescribed information to an investor or potential investor does not refer to a fraudulent scheme but just to property-syndication schemes. The Minister has regulated property syndications under a section which empowers him or her to outlaw illegal schemes. This section does not grant the power to regulate legitimate business practices. In the circumstances the Minister has acted ultra vires his powers under the CPA and regulation 15 could well be invalid. $^{77}$

It is suggested that, should the CPA continue to be the primary means by which such schemes are regulated, it would be more appropriate to draft a code of conduct for the industry under section 82 of the CPA. This section provides for statutory recognition of industry codes of conduct. In other words, a code of conduct could be drafted for those who wish to promote propertysyndication schemes and the Minister, by regulation, may prescribe that this code become the code of conduct for the entire industry. ${ }^{78}$ It would then be prohibited conduct for promoters of such schemes to contravene applicable industry codes, and contraventions could be referred to the Tribunal for a hearing with the result that errant promoters will face the substantial penalties contained in the CPA.

However, it is questionable whether this will solve the problem, especially in light of the fact that there is clear evidence that extensive disclosure documents with complicated legal terminology are not understood or even read by consumers. Extensive legal documents simply serve to create the impression that the business is legitimate. In addition, when promoters comply with the requirements of the CPA (regardless of whether this is complying with regulation 15 or a code of conduct recognized under section 82 ) and the scheme fails, they will be able to argue that as they have complied with CPA and provided the required information no penalty under the CPA can be imposed. ${ }^{79}$ If their arguments are successful, consumers will not be able to claim damages because they may only proceed to the High Court if they first obtain a certificate from the chairperson of the Tribunal certifying that the promoter was engaged in prohibited conduct. There is therefore a critical need to stop such schemes from being promoted in the first place, and it is

77 In Fedsure Life Assurance v Greater Johannesburg TMC 1999 (1) SA 374 the Constitutional Court held that the common-law principles of ultra vires remain under the new constitutional order but they are underpinned and supplemented where necessary by the constitutional principle of legality [par 59]. The court also stated that the "exercise of public power is only legitimate where lawful" [par 56] and that, speaking specifically of the executive and legislative branches of Government in every sphere of Government, it is "central to the conception of our constitutional order" that they are "constrained by the principle that they may exercise no power and perform no function beyond that conferred upon them by law". See also $S v$ Mabena 2007 (1) SACR 482 (SCA) par 2; and Clur v Keil 2012 (3) SA 50 (ECG).

$78 \mathrm{~S} 82(2)$.

79 Obviously this will not apply when it can be shown that the promoters misrepresented the situation but this will require an extensive investigation as the Prakke Report has demonstrated. 
suggested that the most appropriate regulator to deal with this is the FSB through the implementation of the new twin-peaks model of regulation.

\section{The twin-peaks model of financial regulation}

A new development in the pipeline is the introduction of the "twin-peaks" regulatory regime. ${ }^{80}$ The main aim of the policy is to develop institutions which will deal with system-wide prudential risks. All issues relating to the prudential regulation of banks, life assurance companies and possibly other institutions will be placed under the Reserve Bank which is the first peak. ${ }^{81}$ The second peak of the model relates to the market conduct of financial institutions. It is intended that the jurisdiction of the FSB will be substantially increased and the FSB will employ a range of supervisory tools to regulate the market conduct of all financial services providers. Service providers will include banks, insurers, financial advisers, financial intermediaries, investment institutions and the broader financial markets. ${ }^{82}$ Market conduct deals with ensuring that consumers are sold appropriate products that are in their best interest. These supervisory tools will include the traditional tools of regulation such as on-site visits, reviewing compliance reports and other information and issuing requests for information. The FSB will then also be able to employ "mysteryshopper" techniques (that is, making use of anonymous, independent observers who pose as customers seeking information to test how institutions react to potential clients), source information from third parties which will include the media, ombud schemes and consumer bodies, and there will be enhanced reporting requirements from regulated institutions. ${ }^{83}$ The policy document states that the FSB will be empowered to intervene to mitigate emerging conduct risks at both an industry and institution level. The document acknowledges the nature of the risks inherent in the financial sector and that there is a need for regulators to be empowered to act swiftly, without fear, favour or interference. ${ }^{84}$ The regulatory and supervisory framework will enable regulators to assess the risks associated with different regulated activities, systems entities or groups of entities. The frameworks will be sufficiently flexible to ensure that regulatory, supervisory and enforcement approaches are proportionate to the risk and that the frameworks will enable regulators to identify emerging risks to financial stability and consumers as early as possible and grant them the authority to intervene to reduce the likelihood of these risks materializing. ${ }^{85}$ This suggests that the FSB will have powers to

80 See National Treasury "Implementing a twin peaks model of financial regulation in South Africa" 1 February 2013 www.treasury.gov.za/comm_media/press/2013/20103020102\%20 (accessed 2013-04-04). The original policy document was "A Safer Financial Sector to Serve South Africa Better" published in February 2011 (also known as The Red Book).

81 This policy has been developed in response to the financial crisis which was experienced worldwide in 2008. Even though the South African financial system was not as adversely affected as those in other jurisdictions, this crisis highlighted the need for minimum international standards as financial problems affect countries across the globe and are not only restricted to single financial markets. A full discussion of this issue is beyond the scope of this article. Only those developments that have relevance for this discussion are dealt with.

${ }_{82}$ National Treasury "Implementing a Twin Peaks Model" 15.

${ }^{83}$ National Treasury "Implementing a Twin Peaks Model" Chapter 5.

${ }^{84}$ National Treasury "Implementing a Twin Peaks Model" 15.

85 National Treasury "Implementing a Twin Peaks Model" 16. 
stop institutions from promoting products which pose serious risks to consumers. $^{86}$ Enforcement mechanisms will be substantial, including administrative penalties, referrals to an administrative enforcement forum and criminal prosecution. At present the FSB has an existing Enforcement Committee and the new enforcement regime will build on the successes of and lessons learnt from this committee. ${ }^{87}$ The enforcement mechanisms will, however, focus on deterrence. ${ }^{88}$ In order to achieve the aims set out in the policy document, entry to the financial sector will be subject to an appropriate licensing or registration process and the process will include a high standard to determine the fitness and propriety of all players in the financial sector. ${ }^{89}$

It is intended that the twin-peaks model will be implemented in two phases. During 2013 and 2014 legislation will be developed and tabled in Parliament to enable both the Reserve Bank and the FSB to assume their additional responsibilities and sufficient staff will be trained and employed. The second phase will involve harmonizing specific financial regulatory and supervisory systems and frameworks. This phase will be implemented over a number of years. ${ }^{90}$ This suggests therefore that various regulators will work together to create a safer financial market for South African consumers.

The aims set out in the National Treasury policy document are laudable and cannot be faulted. However, it must be questioned whether this is substantially different to what exists at present. The major difference is that the FSB will now have authority over all financial institutions for market conduct including banks, while the Reserve Bank will be responsible for prudential regulation, including prudential regulation over entities such as insurance companies which were previously regulated by the FSB. There will therefore be a clear demarcation between prudential regulation and market-conduct regulation. However, this regulation will only apply to regulated entities. An entity may not fall within the jurisdiction of the FSB because it is not a regulated entity as defined in the applicable legislation. At a hearing held by the parliamentary finance committee in November 2012 where the FSB was questioned regarding a scheme which had defrauded investors out of millions, the FSB stated that the entity concerned fell outside its jurisdiction and there-

86 The extent of these powers and whether or not the FSB will be able to actually prevent such products from being promoted altogether or will be merely empowered to issue warnings is not spelt out in the documents. It is assumed, however, that this will be dealt with in the new legislation.

87 The Enforcement Committee is an administrative body established by statute in the Financial Institutions (Protection of Funds) Act 28 of 2001. Its role is to adjudicate on alleged contraventions of legislation, regulations, codes of conduct, etc administered by the FSB. The Committee may impose unlimited penalties, compensation orders and cost orders. Such orders are enforceable as if they were orders of the High Court.

88 National Treasury "Implementing a Twin Peaks Model" Chapter 7. It is suggested that this is a laudable goal because once the consumer's funds have been lost in a risky or fraudulent investment it is often impossible to recoup the funds from the scheme's promoter. Promoters may be penalized for their conduct by for example losing their licences but this does not help consumers who may not be able to recoup their losses and may be unable to earn again due to their age.

89 National Treasury "Implementing a Twin Peaks Model".

90 National Treasury "Implementing a Twin Peaks Model" Chapter 8. 
fore the FSB was not the responsible regulator. ${ }^{91}$ As stated above, the current definition of a collective investment excludes public-property syndications. The hearing took place at a time when the twin-peaks model was being developed and as the FSB continued in its view that such schemes fall outside its mandate it must be assumed that there is no intention at present to bring such schemes within its jurisdiction. It is assumed that, if there was an intention to change the present position, the FSB would have dealt with the finance committee's questions differently. It seems therefore that, when it comes to public property syndications, it may well be business as usual.

\section{CONCLUSION}

The fact that there are a number of different entities responsible for regulating different aspects of investments schemes is problematic because this allows the unscrupulous to slip under the radar and avoid detection. Regulatory authorities may assume that some other regulator is watching and so by the time they wake up to the problems, consumers have been seriously duped and vast sums of money have disappeared into the pockets of unscrupulous promoters with very little chance of that money being recovered. There is a critical need to ensure that all investment schemes are subject to regulation by a single regulator. This would follow the example set in Australia where a single point of entry for all financial products was created in 2002 precisely in order to stop unscrupulous promoters "from ducking between regulatory regimes or ignoring them altogether". ${ }^{92}$ It is suggested that if South Africa were to adopt a similar approach and subject all public investment schemes to the twin-peaks model this would reduce the number of problem operators. ${ }^{93}$

If the assessment that the twin-peaks model will apply only to regulated entities and that the definition of a collective investment will remain unchanged, then the only form of monitoring by the FSB will be through regulating those that promote such schemes, that is, the FSPs. Harsher penalties may well be considered, such has substantial administrative penalties and loss of licences but it is suggested that this is not sufficient if consumers are to be protected. As the FSB has consistently stated, it considers the conduct of the FSPs and their advisers but it does not regulate the scheme itself. In practical terms this means that the conduct of the FSPs will only come under scrutiny once problems arise and this may mean that it is too late for many consumers who have made substantial investments. It may also be patently unreasonable to expect individual brokers to recognize problems in investment schemes when auditors and regulators have not

91 Approximately 3000 investors invested R2 billion in Herman Pretorius's Relative Value Arbitrage Fund (RVAF). Pretorius was investigated by the FSB in 2011 but the FSB concluded that his activities did not fall within the jurisdiction of the FSB. A year later in 2012 the FSB again decided to investigate Pretorius who then committed suicide after shooting his partner. See Cameron "FSB Passes the Buck on Ponzi Dcams" 25 November 2012 Personal Finance http://www.iol.co.za/business/personal-finance/financial-planning/financial/fsb-passes-the-buck -on-ponzi-scams-1.1429808 (accessed 2013-02-13).

92 Comments made by Dempsey, deputy chief executive of the Association for Savings \& Investment SA and quoted by Cameron "FSB passes the buck on Ponzi scams."

93 Dempsey, deputy chief executive of the Association for Savings \& Investment SA and quoted by Cameron "FSB passes the buck on Ponzi scams." 
identified problems for years. There are abundant reports of investment schemes, both in South Africa and in other jurisdictions, which are highly sophisticated and which use legal instruments to dupe unsuspecting investors and even those employed to promote them. It is therefore essential that all investment schemes promoted to the public should be regulated by the FSB which has trained investigators as well as tools to establish whether schemes are legitimate, and if they are legitimate the risks that are involved for consumers. Public-property syndication schemes should be required to be registered with the FSB before they are promoted to the public, and the new regulatory framework as contemplated in the twin-peaks model must then be applied to such schemes and other forms of investment, thereby making it far more difficult for the unscrupulous to flourish. It must be accepted that there will always be those who will take advantage of the gullible and the imprudent but at least registration with the FSB and the oversight role which it will play will make it much more difficult.

This is said despite the fact that the FSB has been severely criticized in recent times because of its failure to take action against entities which do fall within its jurisdiction. ${ }^{94}$ The question must then be asked whether there is any point in increasing its jurisdiction if it cannot deal with those schemes which it regulates at present. The criticisms are understandable given the prevalence of fraud in South Africa's investment market, but the FSB has been created specifically to deal with such issues and therefore it must be resourced to be able to do the job properly. The twin-peaks model suggests that there is the will to improve the position for South African consumers; it must just be implemented.

A final point needs to be made: legislation can and must be put in place to protect consumers, but the best form of protection will be for consumers to educate themselves about financial matters and to ensure that they understand what they are investing in. At the very least they must ensure that their financial adviser or service provider is properly licenced and adheres to the requirements of the law and that the investments they are choosing are sound. All investors should bear in mind that old adage: "If it sounds too good to be true, it probably is!"

\footnotetext{
94 In its reply to the parliamentary finance committee, the FSB indicated that, where propertysyndications had been promoted, only 5 licences of registered FSPs have been withdrawn and this was after the companies had collapsed. There is also no record of whether or not FSPs or their representatives complied with the FAIS Ombud's directives when FSPs were ordered to repay consumers (Cameron "FSB passes the buck on Ponzi scams"). Orders of the FAIS Ombud have the status of High Court orders but it is up to consumers to enforce them. Where the FSP does not voluntarily comply with orders, consumers have to take further legal action which is often beyond the financial means of most consumers.
} 